\title{
LOSS OF CULTURAL VALUES A THREAT TO BIODIVERSITY IN UTTARANCHAL HIMALAYA
}

\author{
Vijay Prasad Bhatt
}

Scientist, Herbal Research and Development Institute, Gopeshwar, Chamoli, Garhwal, Uttaranchal 246401, India.

\begin{abstract}
The flower festival is one of the important festivals of Hindu communities in Uttaranchal Himalaya celebrated especially to welcome the spring season. The celebrations by various ethnic groups have been studied in detail along with the ethnomusicology of the festival. About 35 plant species or plant-based products have been identified to be associated with this festival. It has been observed that westernisation and urbanisation has had a drastic effect on the ethnic, cultural heritage and religious rituals are on the verge of termination. This paper deals with the ethnobotany of these species in detail.
\end{abstract}

\section{Key words}

Bhotia, ethnic, indigenous, nomadic, tribal, ethnomusicology, ethnobotany

\begin{tabular}{lr}
\multicolumn{2}{c}{ Abbreviations } \\
Bh - Bhotia & B - Byansi \\
C - Chaudansi & D - Darmi \\
F- Family & FF - Flower festival \\
G-Garhwal & J - Johari \\
Jd - Jad r Jn - Jaunsaris \\
Ku - Ethnic Kumaoni other than Bhotia M - Marcha \\
P - Pauri district \\
$\begin{array}{l}\text { Tol - Tolcha U - Ethnic people of Uttarkashi district } \\
\text { other than Bhotia }\end{array}$ \\
VN - Vernacular name(s)
\end{tabular}

\section{Introduction}

Uttaranchal Himalaya has long been a perennial source of diversity in cultural, religious and social traditions, performed by ethnic communities, for generations. The diverse group of communities are ethnic Khasas and Doms distributed mainly in the temperate valleys in Garhwal and Kumaon division of
Uttaranchal State (Bhatt, 2000). The ethnic tribal Bhotia community or semi-nomadic community make their dwelling in the lower valleys of districts Chamoli, Pithoragarh, Uttarkashi, and Bageshwar in the winter months and migrate up to the high Himalaya during the summer months for subsistence and commerical agiculture and to perform various religious ceremonies. However, the Bhotia of district Bageshwar do not practice migration in the summers and lead a life similar to ethnic Khasas and Doms. The Bhotia of Munsiyari Block in Pithoragarh District are known as Johari on account of their migration to Johar Valley (12 summer villages are collectively known as the Johar Valley) along the Gori Ganga River. The Bhotia of Dharchulla block also in Pithoragarh District migrate to Darma known as Darmi, Byans-Byansi and those residing in Chaudas Valley are known as Chaudansi (Atkinson, 1882; Hoon, 1995; Pangti, 1992; Raypa, 1974; Shah \& Jain, 1988).

Other ethnic tribal communities are Gujjar, the real nomadic community and Jaunsaris who are well known for their folkdance and folk-songs. By and large, all the communities other than Gujjars are Hindus, the Jaunsaris are followers of the Muslim religion. Also, the Bhotia of Uttarkashi who are known as Jadhs, Kohli - the weavers and Khampa - the traders, are not totally Hindus; the former two groups maintain both Hinduism and Buddhism while the latter one usually deals only with Buddhism. There are some Khampa inhabiting in the Darma and Byans valleys who also follow Buddhism. Totally, all ethnic communities are rich in cultural and communal rites.

The flower festival is celebrated from the first day of the Chait (March-April) month throughout the region by all ethnic groups except Gujjars and other Muslim communities. Initially, the festival was celebrated only by the ethnic Khasas and Doms but with the passage of time, other tribal groups also joined in this seasonal festival. The festival is celebrated to welcome the spring season and the village god and goddess are worshipped for a good agricultural harvest after the rainy season is over. 


\section{Material and methods}

This study is based on a survey of four districts -- Pithoragarh, Bageshwar, Nainital and Almora in Kumaon division and five districts -- Chamoli, Pauri, Uttarkashi, Dehradun and Tehri in Garhwal division of Uttaranchal Himalaya.

During the field study data on the local names of the festival, identification of the ethnic groups celebrating the festival, collection and identification of the plant species / part (s) used, mode of celebration, ethnomusicology of the festival, important traditional dressed food related to this festival, and mode of immunizing the children on this occasion were collected.

The flower names have been given on the priority/importance basis for each group in Table 1. The ethnomusicology of certain groups have been given in Table 2. Vernacular names of the ethnic groups have been given within parenthesis for better understanding of these species.

\section{Results}

\section{Preparation for the festival}

In some villages of Chamoli District in Garhwal, where Khasas and Doms are main inhabitants, small pretty baskets of Arundinaria sp. (F. Poaceae; G. Ningalo) are coated with a mixture of cow-dung and urine (Godi-mwal-aur-gaunt) and decorated with many small spiral marks of white clay (G. Kamaido; U. Kamad). This basket is prepared to collect and place the flowers. In Tehri, Pauri and Dehradun small baskets are prepared with the husk of wheat and left uncoated. In Kumaon region the flowers are placed on a deep plate (thaal) decorated with coconut (Cocos nucifera, L.; F. Araceae; G. \& K. Golla), a sacred symbol of Goddess Lakshmi. In some villages iron instruments with a bifid/trifid head with a handle (G., P., Ti, U. Talla; K. Ta awo) and a small hammer-like implement (G. Chau (m) phulo / Gaunjo; P., Ti. Chaupad) is made to immunize the children.

\section{Identification of the species used}

The plant species used are given on the basis of priority / importance area-wise in Table 1. The vernacular names of each species used is also given in the same table. Only flowers of the mentioned species are found to be collected by the locals except the leaves of Artemisia nilgirica (Clarke) Pamp. (F. Asteraceae; G. Kundjo, K. Kunja-patti) and Prunus cerasoides, D. Don (F. Rosaceae; G. \& K. Panya).

\section{Mode of celebration}

1. The children of ethnic communities, Khasas and Doms, in villages of Garhwal and Kumaon, except that of Uttarkashi, collect locally available flowers early in the morning in plenty (Table 1) and join in a group. They start singing folk songs (Appendix 1) and the flowers are placed at each doorstep of every house. In Chamoli, the host donate grains, like pulses (dal) like Cajanus cajan (L.) Mill sp. (F. Papilionaceae; G. \&. Tor. Arhad) and Vigna mungo (L.) Hepper (F. Papilionaceae; G. \&. K. Urd), Rice (Oryza sativa L.; F. Poaceae; G. \& K. Chaunl), and money to children while in Kumaon the children are gifted with rice, molasses, a preparation of Saccharum officinarum L (F. Poaceae; G. rikhoo; K. ganna) and money only; and in the evening some women soak rice in water and ground to make sweet rice (K. Shaayaa) cooked with clarified butter (ghee) and some dry fruits like Kaju (Anacardium occidentale L.; F. Anacardiaceae), and Badam (Prunus amygadalus Batsch; F. Rosaceae) etc. In Garhwal, children themselves cook rice and pulses and purchase some sweets from the money they have collected. Some uncooked rice is preserved for Anyar Pooja. Manuscript on Anyar Pooja is under preparation.

In some parts, such as, Block Dasoli in Chamoli, the function was celebrated for one week but now it is restricted to three days. In Pauri the festival still extends for one month and children are offered to eat at the host's house but rice and pulses are not donated; the children are respected with a red mark on their forehead and gifted with some money. In Tehri, the function is celebrated for one month, salted crisp thin cakes (Ti. Papadi) made of ground rice are prepared throughout the month, which on the first day of next month (Baisakh) are fried and distributed among the villagers and family members. Iron instruments are heated till it becomes red, and applied around the umbilicus of children to make them resistant against fatal diseases like polio and indigestion. However, in Pauri this is practiced on Aamawashya of Kartik month after the Deepawali festival is over and also applied on rheumatic pain while, in Tehri District, it is applied only on sprain and during indigestion, and in Kumaon at any time throughout the year during stomach pain and in case of tonsililitis (K. Hanki) of the neck among children. Nevertheless, in every case it needs experts to treat the children.

2. Uttarkashi: The Khasas and Doms in the high altitudes of district Uttarkashi, Block Mori and Patti Panchgain are known as Parvati and of Patti Bangand, in Block Mori are known as Pangandi. They have diverse modes of celebrating the festival. The women stick the flower of Rhododendron arboreum (F. Ericaceae; V.N. Burans-phool) on the doors and door-sill. The children make marks of white clay (U. Kamad) on doors, pots, grain-storing-pots and boxes (Kothar) and on the forehead of domestic and pet animals. The Doms, the survival class, however, collect the cooked items from the Khasas. Children are also immunized. In the Pangandi, a fair is also celebrated in the temple of God Maashi who is said to be the symbol of prosperity and generosity. In Panchgain Patti, the God Someshwar (an idol of Lord Shiva) is worshipped collectively on the second day of the flower festival in the manner similar to God Maashu. 
3. Dehradun: The Tribal Jaunsaris are in the interior parts of Dehradun District. The Jaunsari women stick on their doors the seedlings of barley (Hordeum vulgare (L.) emend; F. Poaceae; V.N. Jau) and wheat (Triticum aestivum L; F. Poaceae; V.N. Gehun) and mark the red vermilion. It is said to help keeping away snakes from family members.

4. Tolcha: They celebrate this festival for two days; first day outside the village and on the second day within the village. In the evening of the Johari Bhotia is similar to Tolcha. However, the celebration by the children in the evening among the Johari Bhotia is known as Gwal Bhattai.

5. Marcha and other Bhotia Group: The celebration is same as above. Here the children also collect the edible oli (B, C, D \& M. Martee; J.\&T. tail; Jd. Mergu). In the evening first rice (B.\& C. Puchchub; D. Puchchum; J. \& T. Chaunl; Jd. Daikwaree; M. $\mathrm{Gaa}$ ) is cooked and this cooking during this festival is known as kukudu jaaga (M.). The cooked rice (B. \& C. Chyaagoo; D. Chaugoo; J. \& T. Bhaat; Jd. Daa; M. Jabba) is first offered to Dyandi Dypta (God Vishnu), then the rice is fried with oil and special salt (B. \& C.Dungcha; D. Kaieen-marcha; J. \& T. Dwangcha; Jd. Maarchu; M. Kaamcha) and seasoned with Allium consanguineum, Kunth, (F. Liliaceae; B. \& C. Jumboo; D. Kwacho; G. Feren; J. Dhunwar; Jd. Jimboo; K. Jamboo; M. Koch; T. Laadum). This rice fried with special salt (B. \& C. Chaagu-Bhutma; D. Bhalma; J. Bhoomal; M. Bhulma) is famous among the Bhotia community. Before eating, a mark of turmeric (Curcuma domestica Val.; F. Zingiberaceae; V.N. Haldo/Peeli pithain) is pressed on the forehead of every child and incense (B.\& C. Nee; J.\& D. Dhoop; M. Posh) is burned and offered to God and Goddess having their place and origin inside the village boundary.

\section{Discussion}

Himalayan indigenous cultures perceive the earth, jungle surrounding the villages, festivals, biological diversity and cropland, soil, biodiversity as existing in the realm of the sacred trust inherited from their ancestors. They developed strong ethics of conservation and evolved communal land tenure systems as the Polynesian indigenous societies had developed (Balick \& Cox, 1996). The grassland, high altitude meadows, flat-lands, forests, water resources and even the croplands are not considered personal property, rather they worshiped the wilderness and crop fields in a collective manner. Until the late 1990s, throughout the Himalayan region important medicinal plants such as Aconite (Aconitum sp.), Allium sp., Dactylorhiza hatagirea, (D. Don) Soo (F. Orchidaceae), Juniperus sp. (F. Cupressaceae), Jurinea dolomiaea Boiss (F. Asteraceae), Arnebia benthamii (Wall. Ex G. Don) I.M. Johnston (F. Boraginaceae), Nardostachys grandiflora DC. (F. Valerianaceae), Picrorhiza kurrooa, Royle ex Benth (F. Scrophulariaceae) and Pleurospermum brunonis Benth (F. Apiaceae) etc. were allowed to be harvested only after the Ashtmi of Bhadra month (after the last week of August) when almost all the species have dehisced their seed for germination in the next year and the potency of active constituents have reached their optimum concentration.

Now every person is engaged in collecting herbs from the wild whenever the availability in nature is assured in maximum quantities especially because of trade (Bhatt, 1999) that has increased substantially even in the remote parts of the Himalaya. Similarly, people had recognized the need to protect vanishing forests, biological resources and used to collect plants yearly on rotation basis from alternate pockets. It was also in practice to wear blurred-color clothes while going into the jungle so that wildlife was not disturbed and everybody was advised not to make excessive noise in the jungle; it was said that the forest goddess would become apparent. These psychological myths and old thoughts and observations are examples of their deep respect and regard for nature and natural environment which have become valueless in the realm of modern civilization and ideology.

The faith and beliefs that our ancestors have inherited had strong relationship with conservation of environment and biological resources but, in practice, thay are now on sharp decline. The commercialization not only of natural forest products but the household commodity have also been treated as an item of commerce pushing every year more and more people to earn enormous amounts of money both by legal and / or illegal means (Bhatt, 1999). Thus a common person would rather have changed from 'conservation-mind' to 'money-mind'. And this changing social aspect is becoming more permanent in the mind of Himalayan societies, especially among the youth.

\section{Conclusion}

In reality, there are few people left within the ethnic populations possessing a fuller acquaintace with their social, cultural and religious rites. Yet, in the interior parts of the Himalaya where the social and cultural rituals are celebrated they were never appreciated or respected for retaining the aboriginal knowledge of civilization. For most times, people in the remote regions face the ridicule of persons residing in towns who commonly call the former community as 'kaachchaa lwag' (rough and immature people). These remote Himalayan people are also ignored by the government- and non-government organizations while making any development plans for the higher Himalayan region. However, most of the projects basically are prepared with a view to benefit these people directly. More often, the project ends merely with the hypothetical rather than practical support.

While all of the above points are relevant to the problems of preserving cultural and religious diversity in the Himalaya, it would be necessary to have a comprehensive understanding of 


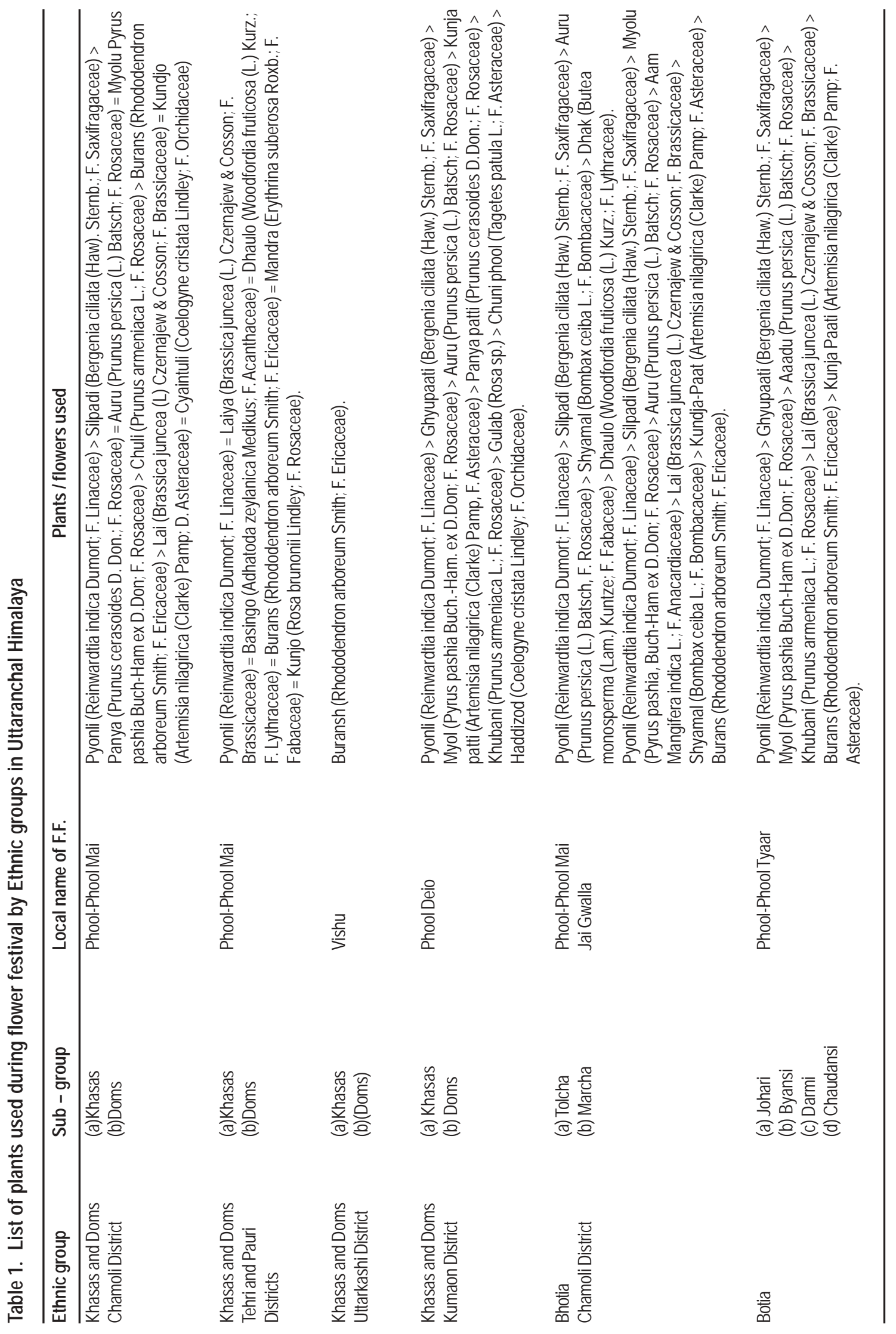


the ethnic people, their social relationship and overall education and health problem. A large number of factors like population, traditional arts and ethics, mode and manner of eating and drinking, dialects spoken and administrative convenience are at present important considerations for policy makers and implementing authorities / organizations of our societies.

\section{References}

Atkinson, E.T. (1882). The Himalayan Districts of North West Provinces of India. Cosmopolitan Publications, New Delhi (reprinted 1973).

Balick. M.J. and P.A. Rox (1976). Plants, People and Culture. The Science of Ethno-botany, W.H. Freeman \& Co. New York.

Bhatt, V.P. (1999). Ethnobiology of high altitude Himalayan communities in district Chamoli: A conservation perspective. Zoos' Print Journal 2-11: 137-146.

Bhatt, V.P. (2000). Conservation of some medicinal and aromatic plants wealth in high altitude of Uttaranchal Himalaya, pp. 129-144. In: Mukerji, K.G., B.P. Chamola and A.K. Sharma (Editors.). Glimpses in Botany. A.P. H. Publication Corporation, New Delhi,

Hoon, V. (1995). Living on the Move: Bhotia of the Kumaon Himalaya Sage Publication, New Delhi.

Pangti, S.S. (1992). Shauka-Seemavarti Janjaati. Raypa Brothers, Dharchula, Pithoragarh.

Raypa, S.S. (1992). Bhotia Tribe of Central Himalaya. Taksh-shila Prakashan, New Delhi.

Shah, N.C. and S.K. Jain (1988). Ethno-medico-botany of the Kumaon Himalay. Indian Society of Pharmacology 2(4): 359-380.

\section{Appendix 1. Ethnomusicology of flower festival}

\begin{tabular}{|c|c|}
\hline Ethnic group & Phool-phool mai, kool-kool khaja dei \\
\hline$\overline{\text { Bhotia (Tolcha) }}$ & Dal dei, chaul dei, namak dei mirch dei \\
\hline Bhotia (Marcha) & $\begin{array}{l}\text { Jai gwalla pyonli ka phoola, } \\
\text { Chaunl dei dal dei, meri tokari bhaur dei } \\
\text { Jai gwalla silpadi ka phoola, } \\
\text { Chaunl dei dal dei, meri takari bhaur dei } \\
\text { Jai gwalla myolu ka phoola, } \\
\text { Chaunl dei dal dei, meri tokari bhaur dei } \\
\text { Jai gwalla aaru ka phoola, } \\
\text { Chaunl dei dal dei, meri tokari bhaur dei, } \\
\text { Jai gwalla aam ka phoola, } \\
\text { Chaunl dei dal dei, meri tokari phaur dei, } \\
\text { Jai gwalla lai ka phoola, } \\
\text { Chaunl dei dal dei, meri tokari bhaur dei. }\end{array}$ \\
\hline $\begin{array}{l}\text { Khasas and Doms } \\
\text { (Chamoli) }\end{array}$ & $\begin{array}{l}\text { (1) Phool-phool mai, dal dei chaunl dei } \\
\text { Phool-phool mai, dal dei chaunl dei } \\
\text { (2) Wabrai budali dal dei chaunl dei, } \\
\text { Jhangor na dei khaja dei gwaga jai maata jai, } \\
\text { Phool-phool mai dal dei, chaunl dei } \\
\text { Jai gwaga pyunla phool, jai gwaga buransa phool } \\
\text { Jai gwaga syantula phool, jai gwaga myola phool } \\
\text { Jai gwaga silpadi phool, jai gwaga arwa phool } \\
\text { Gwaga jai, maata jai, phool mai dal dei chaunl dei. } \\
\text { (3) Aaru ki-hadaili, maasi-ko-dhoop } \\
\text { Jai-jai gwaga pyonli-ko-roop. }\end{array}$ \\
\hline Bhotia (Pithoragarh) & $\begin{array}{l}\text { Phool phool, phool phool } \\
\text { Phool phool, phool phool }\end{array}$ \\
\hline $\begin{array}{l}\text { Khasas and Doms } \\
\text { (Kumaon) }\end{array}$ & $\begin{array}{l}\text { Phool dei, chamma dei } \\
\text { Phool dei, chamma dei. }\end{array}$ \\
\hline
\end{tabular}

